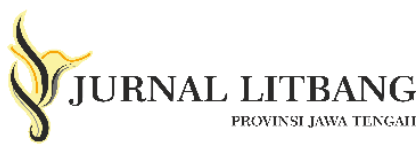

\author{
Info Artikel \\ Diterima : 30 Agustus 2021 \\ Direvisi : 22 Desember 2021 \\ Disetujui : 23 Desember 2021 \\ Kata kunci: \\ Covid-19 \\ Google Mobility \\ Kebijakan \\ Korelasi
}

Keywords:

Correlation

Covid-19

Google Mobility

Policy

Corresponding Author:

Bagus Nuari Priambudi bagusnuaripriambudi@

live.undip.ac.id

+6282265140088

\section{Pengaruh Kebijakan PPKM Tahap II Jawa Tengah Terhadap Mobilitas Penduduk Pada Sektor Retail dan Rekreasi}

\author{
The Effect of PPKM Phase II Central Java \\ Policy on Population Mobility in the Retail and \\ Recreation Sectors
}

Bagus Nuari Priambudi, Nofa Martina Ariani, Muhammad Indra Hadi Wijaya, Brian Pradana Diploma 3 PTWRK PSDKU, Sekolah Vokasi Universitas Diponegoro, Semarang

\begin{abstract}
Abstrak
Mobilitas penduduk perkotaan menuju ke sektor potensial merupakan salah satu bentuk perputaran kegiatan ekonomi. Namun kondisi tersebut, saat ini terganggu karena adanya Covid-19. Kondisi ini terjadi hampir di seluruh dunia, tak terkecuali Indonesia. Untuk menekan penyebaran wabah yang semakin pesat, beberapa kebijakan dikeluarkan supaya dapat memangkas mobilitas penduduk yang tinggi. Artikel ini bertujuan untuk mengetahui pengaruh dari penerapan kebijakan PPKM Tahap II terhadap Mobilitas Penduduk pada sektor retail dan rekreasi. Artikel ini menggunakan pendekatan kajian pustaka dengan mengolah data google mobility report, sehingga diketahui korelasi terhadap variable yang diuji. Kebijakan PPKM Jateng Tahap II dapat mempengaruhi mobilitas penduduk menuju sektor retail dan rekreasi. Adanya kebijakan tersebut, secara tidak langsung membatasi ruang aktivitas masyarakat dalam melakukan pergerakan.
\end{abstract}

\begin{abstract}
The mobility of urban populations towards potential sectors is one form of economic activity turnover. However, this condition is currently disrupted due to Covid-19. This condition occurs almost all over the world, not least Indonesia. To suppress the rapid spread of the outbreak, several policies were issued in order to reduce the mobility of the high population. This article aims to find out the influence of the implementation of PPKM Phase II policy on Population Mobility in the retail and leisure sectors. This article uses a library study approach by processing google mobility report data, so that the correlation to variables tested is known. PPKM Central Java Phase II policy can affect the mobility of the population towards the retail and leisure sectors. The existence of this policy, indirectly limits the space of community activities in making movements.
\end{abstract}




\section{PENDAHULUAN}

Pandemi Covid-19 merupakan suatu kondisi adanya wabah penyakit hampir di seluruh dunia dengan tingkat penyebaran yang mengkhawatirkan. Hal ini membuat WHO menetapakan kondisi pandemi global mulai 11 Maret 2 (Ghiffari, 2020). Wabah ini awalnya muncul dari Wuhan, China. Pada negara asalnya wabah ini memberikan pengaruh yang cukup besar pada aspek kehidupan ekonomi, sosial, pendidikan, dan tidak terkecuali kesehatan (Nugroho \& Kasuma, 2020). Kasus perkembangan wabah ini juga semakin berkembang pesat dalam jangka waktu beberapa bulan ke negara eropa, amerika utara, asia dan timur tengah (Bedford et al., 2020). Pesatnya penyebaran wabah ini dipengaruhi adanya interaksi kuat antara dua faktor penting. Interaksi tersebut terjadi karena kemampuan penularan patogen yang bertanggung jawab atas infeksi dan karakteristik populasi manusia sebagai inang dalam perkembangbiakan patogen (Merler \& Ajelli, 2010). Penyebaran wabah COVID-19, selain dipengaruhi oleh faktor spesifik patogennya, juga dipengaruhi oleh struktur populasi dan mobilitas penduduk sebagai kerentanan sosial dalam menghadapi wabah penyakit, antara lain: kepadatan penduduk, kemiskinan, aktivitas sosial ekonomi di luar rumah, dan perjalanan antar kota (Sands, El Turabi, Saynisch, \& Dzau, 2016)

Konsentrasi penduduk yang tinggi, terutama di bagian pusat kota yang memiliki permukiman informal yang padat, dapat menjadi episentrum penularan penyakit dan mempercepat penyebaran patogen (Neiderud, 2015).

Kondisi permukiman kumuh dengan kebersihan lingkungan dan sanitasi yang buruk juga dapat meningkatkan indeks kerentanan terhadap wabah penyakit ini (Toole \& Waldman, 1990). Hingga saat ini, wabah tersebut juga terus berkembang hampir di seluruh dunia, tak terkecuali di Indonesia. Kasus pertama Covid-19 di Indonesia diprediksi oleh Riono sudah mulai ada pada Januari - awal Februari 2020 (Yurianto, 2020). Hal ini mengindikasikan bahwa kondisi ini harus benar benar ditangani secara serius supaya penyebaran wabah ini tidak semakin mengkhawatirkan. Pemerintah pusat dan daerah bersinergi dengan membuat kebijakan untuk dapat menekan angka penyebarannya.

Provinsi Jawa Tengah, tercatat menyumbang angka penyebaran kasus yang cukup tinggi hingga awal tahun 2021. Kasus tersebut diprediksi terjadi karena mobilitas masyarakat setiap hari cukup tinggi ke beberapa sektor potensial. Untuk mengatasi hal tersebut, Pemerintah Pusat bekerja sama dengan Pemerintah Provinsi mengeluarkan kebijakan PSSB (Pembatasan Sosial Sekala Besar) Tahap I Jawa Bali Tanggal 11 - 25 Januari 2021 dan PSBB Tahap II Tanggal 26 Januari - 8 Februari. Kebijakan tersebut, dinilai cukup efektif menekan mobilitas masyarakat.

Guna memperkuat kebijakan yang berasal dari tingkat pusat, Pemerintah Provinsi Jawa Tengah, membuat kebijakan yang tertuang dalam Surat Edaran (SE) Nomor 443.5/0001933 tanggal 2 Februari 2021.

Surat edaran tersebut berisi tentang Peningkatan Kedisiplinan dan Pengetatan Protokol Kesehatan Pada Pemberlakuan Pembatasan Kegiatan Masyarakat (PPKM) Tahap II di Jawa Tengah (Hidayah, 2021). PPKM tahap II dilakukan pada tanggal $6-7$ Februari dan dilanjutkan pada tanggal 9 Februari 2021. Pada SE tersebut terdapat 7 sektor yang dibatasi kegiatanya Car Free Day, penutupan jalan, toko/mall, pasar, pariwisata, acara hajatan dan kegiatan yang menimbulkan kerumunan. Ketujuh sektor tersebut, diperkirkan menyumbang mobiltas masyarakat cukup tinggi. Penulisan artikel ini bertujuan untuk mengetahui pengaruh dari penerapan kebijakan PPKM Tahap II terhadap mobilitas penduduk pada sektor retail dan rekreasi. Karena dua sektor ini merupakan sektor potensial yang 
menyumbang pendapatan daerah tinggi di Provinsi Jawa Tengah.

\section{METODE PENELITIAN}

Artikel ini fokus menggunakan metode penelitian kepustakaan (library research). Sumber data dan informasi utama berasal dari media massa, jurnal maupun artikel dengan tema yang sama dengan penelitian (Wahyudin, 2018). Data yang digunakan pada penelitian ini bersumber dari Google Community Mobility Report.

Penelitian ini berdasar pada penelitian sebelumnya yang dilakukan oleh (Wang \& Yamamoto, 2020) yang melakukan peramalan kasus COVID-19 dengan bantuan data aktivitas manusia dari Google Community Mobility Report menggunakan Partial Differential Equation (PDE). Selain itu, Sampai dan (Sampi Bravo \& Jooste, 2020) melakukan penelitian menggunakan data dari Google Community Mobility Report untuk menghitung Google Mobility Index yang digunakan sebagai indikator tingkat pertumbuhan produksi industri bulanan di negara tertentu.

Data Google Community Mobility Report merupakan data yang dikumpulkan oleh Google dari para ponsel penggunanya (Nugroho \& Kasuma, 2020). Data ini akan menunjukkan perubahan kunjungan ke berbagai tempat, seperti toko bahan makanan dan taman, di setiap wilayah geografis (Google, 2021). Artikel ini menggunakan data pada rentan waktu sebelum dan setelah pelaksanaan PPKM Tahap II di Jawa Tengah. Pendekatan yang digunakan dalam artikel ini adalah tradisional dan sistematik. Pendekatan ini dapat bersifat review kritis, konseptual review, review pada tema penelitian tertentu, maupun review yang dikemukakan oleh para ahli (Jesson, Matheson, \& Lacey, 2011). Pembahasan yang ditekankan pada artikel ini cenderung bersifat review policy. Review Policy ini bertujuan untuk memberikan pemahaman yang lebih spesifik tentang suatu konsep yang sudah diterapkan. Penelitian ini memiliki empat tahapan yang dilakukan. Pertama, identifikasi terhadap kebijakan yang berkaitan dengan tema penelitian. Kedua, melakukan pencarian data dan informasi faktual dan teoritis yang relevan. Ketiga, melakukan review terhadap informasi yang sudah dikumpulkan secara objektif. Kemudian hasil review tersebut, disusun menjadi informasi yang akurat dan terpercaya. Harapannya hasil dari artikel ini dapat memberikan informasi hasil penelitian kepustakaan yang dapat dipertanggungjawabkan berdasarkan sumber data yang dapat dipercaya secara faktual dan teoritis (Behrends, Lindholm, \& Woxenius, 2008).

\section{HASIL DAN PEMBAHASAN}

Mobilitas penduduk perkotaan mulai mengalami penurunan, sejak ditemukannya kasus pertama Covid-19 di Indonesia sekitar bulan maret 2020. Gambar 1 menunjukan adanya penurunan mobiltas penduduk menuju 7 sektor potensial perkotaan (Februari 2020 - April 2021). Rata rata penurunan mobilitasnya mencapai $>50 \%$. Bahkan pada penggunaan sektor transportasi umum berkurang mencapai > $60 \%$. Penerapan adaptasi kebiasan baru (New Normal) juga belum bisa memulihkan kondisi mobilitas penduduk.

Hal ini mengindikasikan adanya efek cukup siginifikan, yang membuat orang lebih safety memilih menggunakan transportasi pribadi. Frekuensi perjalanan secara positif mempengaruhi kepemilikan kendaraan pribadi. Mobilitas tinggi seseorang, akan membutuhkan kendaraan yang dapat diandalkan, dan dalam penelitian di berbagai negara, kendaraan yang dapat diandalkan adalah kendaraan pribadi (Primerano, Taylor, Pitaksringkarn, \& Tisato, 2008).

Selain itu, perjalanan untuk keperluan potensial, terutama perjalanan yang membutuhkan ketepatan waktu ke tempat tujuan banyak menggunakan kendaraan pribadi (Warpani, 1990). 


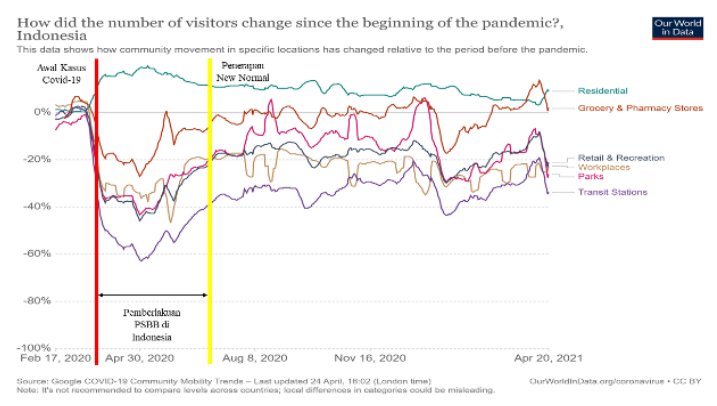

Gambar 1. Perubahan Mobiltas Penduduk Akibat Pandemic Covid19

Sumber: Google Mobility Trend, 2021

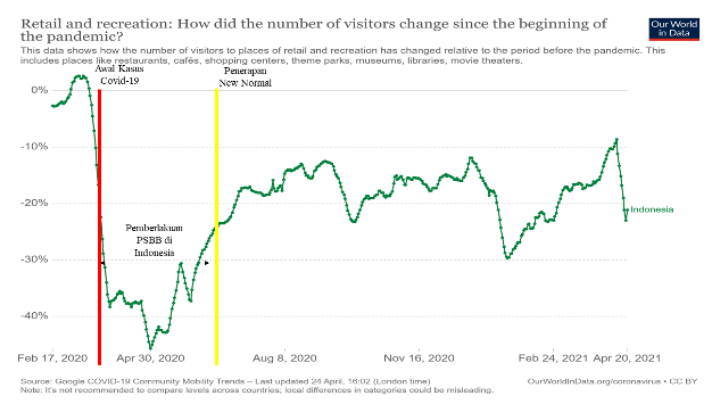

Gambar 2. Mobilitas Penduduk menuju ke Ritel dan Rekreasi akibat Pandemic Covid19

Sumber: Google Mobility Trend, 2021

Sejalan dengan kondisi pada Gambar 1, mobilitas penduduk menuju ke sektor retail dan rekreasi juga cukup berdampak besar. Penurunanya hingga mencapai $40 \%$ di bulan April 2021 (Gambar 2). Penerapan adaptasi kebiasaan baru, juga belum bisa membuat peningkatan yang siginfikan untuk berkunjung kesana. Menurunya jumlah kunjungan orang berdampak pada perputaran ekonomi yang semakin menurun. Penurunan mobilitas penduduk ini, juga terjadi di Jawa Tengah.

Kebijakan PSBB Jawa Bali Tahap 1-2 serta PPKM Tahap 2 Jateng dan PPKM mikro cukup efektif mengurangi mobilitas penduduk menuju sektor retail dan rekreasi. Hasil analisa data yang berasal dari Google Mobility Trend pada Gambar 3, pada periode waktu PPKM Jateng Tahap II mobilitas penduduk menuju retail dan rekreasi menurun hingga 21.000 pergerakan/ minggu. Sedangkan pada penerapan PPKM Mikro leih efektif menekan mobilitas hingga 44.000 pergerakan/ minggunya.

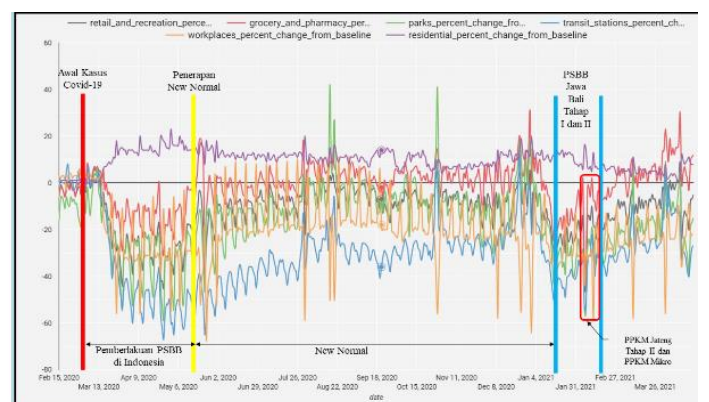

Gambar 3. Jumlah Mobilitas Penduduk menuju ke Ritel dan Rekreasi Akibat PPKM Jateng Tahap II

Sumber: Google Mobility Trend, diolah Kembali, 2021

Jika dilihat dari data diatas, adanya kebijakan yang dikeluarkan oleh Pemerintah Provinsi Jawa Tengah secara signifikan mempengaruhi mobilitas penduduk. Untuk melihat hubungan korelasinya, dilakukan analisa korelasi pearson $r$ dengan bantuan software SPPS. Pada penelitian ini variable independent yang diuji adalah Jumlah Penduduk dan Tingkat Mobilitas. Sedangkan variable dependent yakni jumlah kasus positif Covid-19 di Jawa Tengah.

Tabel 1. Analisa Korelasi Pearson $r$

\begin{tabular}{lll}
\hline No & Variabel & Pearson $\mathrm{r}$ \\
\hline 1 & Jumlah Penduduk & 0,5531 \\
2 & Tingkat Mobilitas & 0,5416 \\
& Penduduk & \\
\hline
\end{tabular}

Sumber: Analisa Peneliti,2021

Hasil uji korelasi pada Tabel 1 menunjukan, nilai pearson $r$ untuk jumlah penduduk $(0,5531)$ dan mobilitas penduduk (0,5461). Menurut (Schober, Boer, \& Schwarte, 2018) Nilai korelasi Pearson (r) terbagi menjadi beberapa interval nilai, yakni: 0,1 - 0,39 (korelasi lemah); 0,4-0,69 (korelasi menengah); $0,7-0,89$ (korelasi kuat); dan 0,9 - 1,0 (korelasi sangat kuat). Apabila korelasi (r) sebesar $<0,1$ dapat diabaikan, atau pada beberapa penelitian ditetapkan angka $(r)<0,03$ sebagai nilai 
Jurnal Litbang Provinsi Jawa Tengah, Vol. 19, No. 2, Desember 2021, hal. 189 - 194

korelasi yang diabaikan (Nishimura et al.,2016). Hasil tabel 1 menunjukan bahwa pada dua variable yang diuji, secara statistik memiki korelasi menengah. Korelasi tersebut, secara kuat dapat mempengaruhi variable dependentnya. Hal ini, dibuktikan dengan adanya penurunan mobilitas penduduk menuju ke retail dan rekreasi ketika penerapan kebijakan tersebut.

Tabel 2. Korelasi 2 Variabel Terkait

\begin{tabular}{lll}
\hline \multirow{2}{*}{ Variabel } & \multicolumn{2}{l}{ Pearson R } \\
\cline { 2 - 3 } & $\begin{array}{l}\text { Sektor } \\
\text { Retail }\end{array}$ & $\begin{array}{l}\text { Sektor } \\
\text { Rekreasi }\end{array}$ \\
\hline $\begin{array}{l}\text { Mobilitas } \\
\text { Penduduk }\end{array}$ & 0,7659 & 0,7345 \\
\hline
\end{tabular}

Sumber: Analisa Peneliti,2021

Untuk memperkuat hasil analisis sebelumnya, uji pearson $\mathrm{R}$ dilakukan pada dua variable independentnya. Pada tabel 2 menunjukan bahwa nilai korelasi antara dua variable berada pada kisaran nilai $0,7-0,89$.

Hal ini mengindikasikan bahwa pada dua variable ini memiliki hubungan yang kuat.

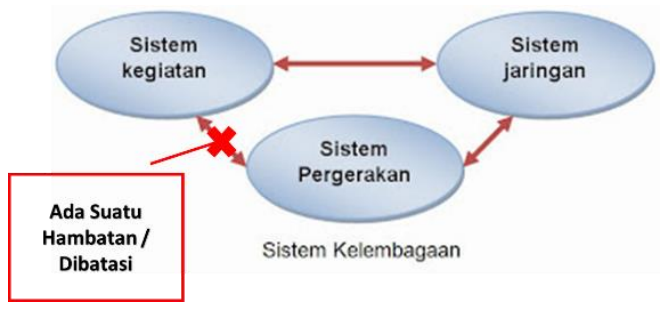

Gambar 4. Adanya Hambatan Berpengaruh Terhadap Sektor Lain Dalam Transportasi Makro

Sumber: Ofyar Tamin, 2000 dan diolah Kembali, 2021

Hasil analisis ini sejalan dengan yang disampaikan oleh (Tamin, 2000) dalam segitiga transportasi makro. Gambar 4 mengilustrasikan apabila ada satu sisi pergerakan/hal lain yang dibatasi/dihambat pasti akan berpengaruh terhadap semua sektor yang ada didalamnya.

\section{SIMPULAN}

Kebijakan PPKM Jateng Tahap II secara statistis signifikan memiliki korelasi sedang untuk mempengaruhi mobilitas penduduk menuju sektor retail dan rekreasi. Adanya kebijakan tersebut, secara tidak langsung membatasi ruang aktivitas masyarakat dalam melakukan pergerakan.

\section{UCAPAN TERIMAKASIH}

Artikel ini merupakan salah satu fokus penelitian dalam program studi Diploma 3 Perencanaan Tata Ruang Wilayah dan Kota. Penulis mengucapkan terima kasih kepada Lembaga Pengelola Program Studi Diluar Kampus Utama, Sekolah Vokasi Universitas Diponegoro karena telah memfasilitasi penelitian ini. Selain itu juga kepada para dosen lainya yang menyempatkan waktu untuk berdiskusi dan memberikan wawasan terbaru terkait topik penelitian ini. Semua itu bertujuan untuk membantu penulis dalam menyelesaikan artikel ini. Penulis menyadari bahwa artikel ini masih banyak kekurangan. Sehingga kedepannya perlu ditingkatkan kembali untuk dapat berkontribusi yang lebih berkualitas pada topik penelitian.

\section{DAFTAR PUSTAKA}

Bedford, J., Enria, D., Giesecke, J., Heymann, D. L., Ihekweazu, C., Kobinger, G., . . . Schuchat, A. (2020). COVID-19: towards controlling of a pandemic. The lancet, 395(10229), 1015-1018.

Behrends, S., Lindholm, M., \& Woxenius, J. (2008). The impact of urban freight transport: A definition of sustainability from an actor's perspective. Transportation planning and technology, 31(6), 693-713.

Ghiffari, R. A. (2020). Dampak populasi dan mobilitas perkotaan terhadap penyebaran pandemi COVID-19 di Jakarta. Tunas Geografi, 9(1), 81-88.

Google. (2021). Laporan Mobilitas Masyarakat Selama Pandemi COVID-19 di Indonesia April 2021. Retrieved from https://www.google.com/covid19/mo bility 
Hidayah, N. (2021). Info Jateng Terkini \& Alasan Kebijakan Jateng di Rumah Saja 2 Hari. Tirto.id. Retrieved from https://tirto.id/info-jateng-terkinialasan-kebijakan-jateng-di-rumahsaja-2-hari-f91B

Jesson, J., Matheson, L., \& Lacey, F. M. (2011). Doing your literature review: Traditional and systematic techniques.

Merler, S., \& Ajelli, M. (2010). The role of population heterogeneity and human mobility in the spread of pandemic influenza. Proceedings of the Royal Society B: Biological Sciences, 277(1681), 557-565.

Neiderud, C.-J. (2015). How urbanization affects the epidemiology of emerging infectious diseases. Infection ecology \& epidemiology, 5(1), 27060.

Nugroho, Y. D., \& Kasuma, K. A. P. (2020). Analisis Perubahan Mobilitas Terhadap Proses Remediasi Dampak Covid-19 Di Indonesia Menggunakan Data Google Mobility. Paper presented at the Seminar Nasional Official Statistics.

Primerano, F., Taylor, M. A., Pitaksringkarn, L., \& Tisato, P. (2008). Defining and understanding trip chaining behaviour. Transportation, 35(1), 5572.

Sampi Bravo, J. R. E., \& Jooste, C. (2020). Nowcasting economic activity in times of COVID-19: An approximation from the Google Community Mobility Report. World Bank Policy Research Working Paper(9247).
Sands, P., El Turabi, A., Saynisch, P. A., \& Dzau, V. J. (2016). Assessment of economic vulnerability to infectious disease crises. The lancet, 388(10058), 2443-2448.

Schober, P., Boer, C., \& Schwarte, L. A. (2018). Correlation coefficients: appropriate use and interpretation. Anesthesia \& Analgesia, 126(5), 1763-1768.

Tamin, O. Z. (2000). Perencanaan dan pemodelan transportasi: Penerbit ITB.

Toole, M. J., \& Waldman, R. J. (1990). Prevention of excess mortality in refugee and displaced populations in developing countries. Jama, 263(24), 3296-3302.

Wahyudin, D. (2018). Peluang Dan Tantangan "Big Data" Dalam Membangun "Smart City" Untuk Sistem Transportasi. Jurnal Reformasi Administrasi: Jurnal Ilmiah untuk Mewujudkan Masyarakat Madani, 5(2), 109-115.

Wang, H., \& Yamamoto, N. (2020). Using a partial differential equation with Google Mobility data to predict COVID-19 in Arizona. arXiv preprint arXiv:2006.16928.

Warpani, S. (1990). Merencanakan Sistem Transportasi. Penerbit ITB, Bandung.

Yurianto, A. (2020). Ungkap Corona Masuk RI Sejak Januari , Pakar UI : Pemerintah Menyangkal Terus. Detik.com, pp. 1-6. Retrieved from https://news.detik.com/berita/d4983470/ungkap-corona-masuk-risejak-januari-pakar-ui-pemerintahmenyangkal-terus 